\title{
NUMERICAL MODEL FOR LOCAL KNEADING OF GLASS FIBER- REINFORCED BEAM
}

\author{
Sanja Junušić \\ Josip Juraj Strossmayer University of Osijek, Faculty of Civil Engineering Osijek, mag.ing.aedif. \\ Tihomir Štefić \\ Josip Juraj Strossmayer University of Osijek, Faculty of Civil Engineering Osijek, mr.sc. \\ Aleksandar Jurić \\ Josip Juraj Strossmayer University of Osijek, Faculty of Civil Engineering Osijek, Associate Professor \\ Corresponding author: ajuric@gfos.hr
}

\begin{abstract}
This paper presents an analysis of the deformations in hollow cross-sectional beams made of multilayer glass fiber-reinforced polymer at force application positions. A non-linear numerical analysis is conducted on a beam with a rectangular cross-section and familiar dimensions and material characteristics. Three beams with different spans that are all loaded with two concentrated forces are analyzed, where the distance of the forces from the supports is varied. The kneading deformations at the vicinity, where the two concentrated forces are applied, are monitored with regard to force increase. The results are shown in dimensionless diagrams, wherein the ratio of the actual and initial forces is related to the ratio of deformations at the force application points and mid-span.
\end{abstract}

Keywords: glass fiber-reinforced polymer; concentrated force; non-linear numerical analysis; kneading deformation; dimensionless diagram

\section{NUMERIČKI MODEL LOKALNOG GNJEČENJA NOSAČA OD STAKLOPLASTIKE}

Sažetak: U radu se analiziraju deformacije kod šupljih nosača od višeslojnog polimera ojačanog staklenim vlaknima (stakloplastika) na mjestima djelovanja koncentriranih sila. Nelinearna numerička analiza je provedena na nosaču pravokutnog poprečnog presjeka s unaprijed odabranim dimenzijama i karakteristikama materijala. Analizirani su nosači s tri različita raspona, a svaki je opterećivan dvjema koncentriranim silama, gdje je varirana udaljenost sila od oslonaca. Za postepeno povećanje sile praćena je promjena vrijednosti deformacije gnječenja na mjestima opterećenja. Rezultati su prikazani bezdimenzionalnim dijagramima, odnosno, za omjer pripadne sile s početnom silom prati se omjer deformacije na mjestu opterećenja i u polovini raspona.

Ključne riječi: polimer ojačan staklenim vlaknima; koncentrirana sila; nelinearna numerička analiza; deformacija gnječenja; bezdimenzionalni dijagram 


\section{INTRODUCTION}

The mechanical properties of polymers depend on the material structure and temperature during production and usage. Polymers are generally brittle materials. As such, they have moderate resistance to temperature increase and mechanical resistance $[1,2]$. Meanwhile, they can have significant resistance to atmospheric effects when the components are carefully selected and treated during production. Other materials and reinforcements are added to polymers to improve these characteristics, which results in different types of composites that are capable of meeting different environmental and mechanical requirements. One of the most commonly used composites is the glass fiber-reinforced polymer (GFRP). GFRP is a combination of polymers (i.e., polyester resin) reinforced with glass fiber with different fiber orientations (e.g., random, unidirectional, mat, etc.). A beam composed of such a material with a hollow cross-section has been investigated in [3] and [4]. This beam was intended for use in different floor and ceiling structures. Basic material characteristics are tested on samples that are most commonly prepared for simple tensile testing, such as those prepared in [4] and described in [5]. The present study uses those characteristics to develop a numerical model. GFRP behaves as a brittle material at small intensities of applied force. The polymer then behaves elastically as the force increases, after which, a minimal plastic deformation appears before failure. This behavior is observed at the $\sigma-\varepsilon$ diagram taken from those tests (Figure 1). This diagram also shows the brittle fracture nature of the material.

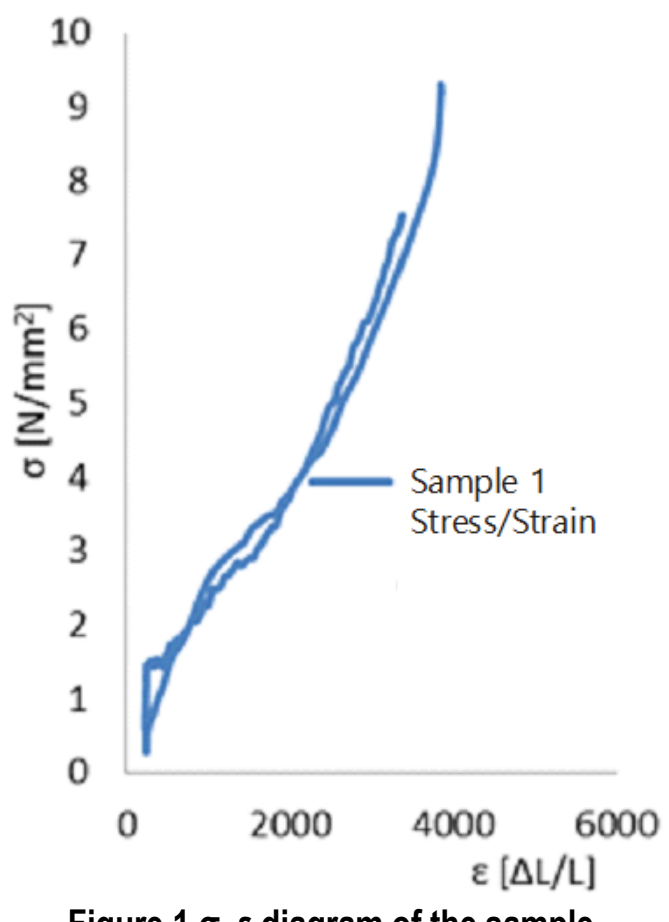

Figure $1 \sigma-\varepsilon$ diagram of the sample

This paper contributes to the experimental and numerical analyses of the beams investigated in [3] and [4]. The beams were experimentally tested with the four-point bending test and numerically investigated with the Autodesk Robot software package [6]. The numerical and experimental analyses point to significant stress and deformation concentrations at the vicinity of the concentrated forces, which are at the force application points and supports. This issue is unfavorable for GFRP and similar beams and cross sections. Figure 2 [4] shows the consequence of this problem.

This issue defines beam failure as a brittle failure. Although GFRP is a brittle material, this result is unfavorable, and should be avoided when possible. The advantage of the GFRP material is that its failure can be easily detected. Failure occurs because of progressive fiber failure and/or matrix and fiber separation.

This study analyzes the ratio of the vertical deformation from the concentrated forces in the area, where the force is applied opposed to the total vertical mid-span deflection. A similar analysis has been conducted in [3] at the supports area. The results of both investigations are analyzed in this paper. 


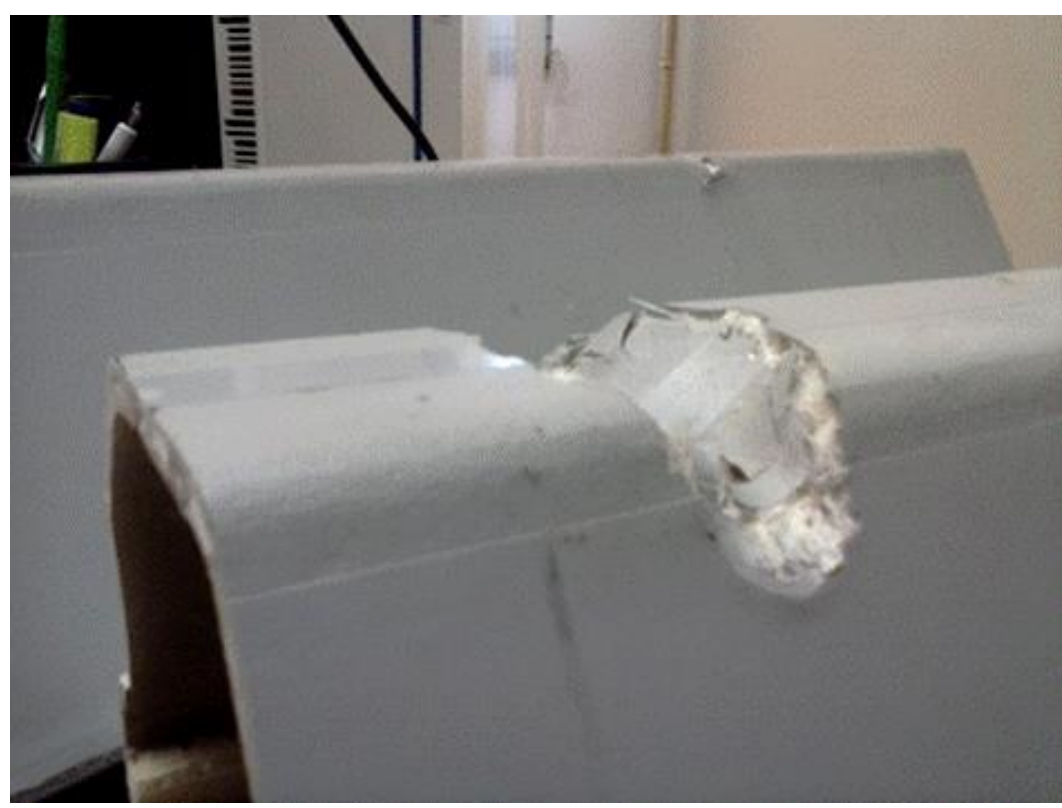

Figure 2 Local beam deformation [4]

\section{NUMERICAL MODEL}

This study conducted a numerical analysis on a non-linear numerical model taken from [3] by using the Autodesk Robot software package [6]. A simply supported beam, as shown in Figure 3, was used as the model. The material and geometrical characteristics were taken from [3]. The material characteristics are as follows: $E=7000 \mathrm{~N} / \mathrm{mm}^{2}$; $v=0.3 ; G=400 \mathrm{~N} / \mathrm{mm}^{2} ;$ and $f_{d}=60 \mathrm{~N} / \mathrm{mm}^{2}$. Three beams with different spans (i.e., $\mathrm{L}=90 \mathrm{~cm} ; \mathrm{L}=140 \mathrm{~cm}$; and $\mathrm{L}$ $=240 \mathrm{~cm}$ ) were also analyzed. The cross-section had a height of $100 \mathrm{~mm}$, width of $60 \mathrm{~mm}$, and flange thickness of $9 \mathrm{~mm}$. The beams were loaded with two concentrated forces. Accordingly, the distance between the forces and the supports for every beam was varied in values of $6 \%, 11 \%$, and $17 \%$ of the beam span.

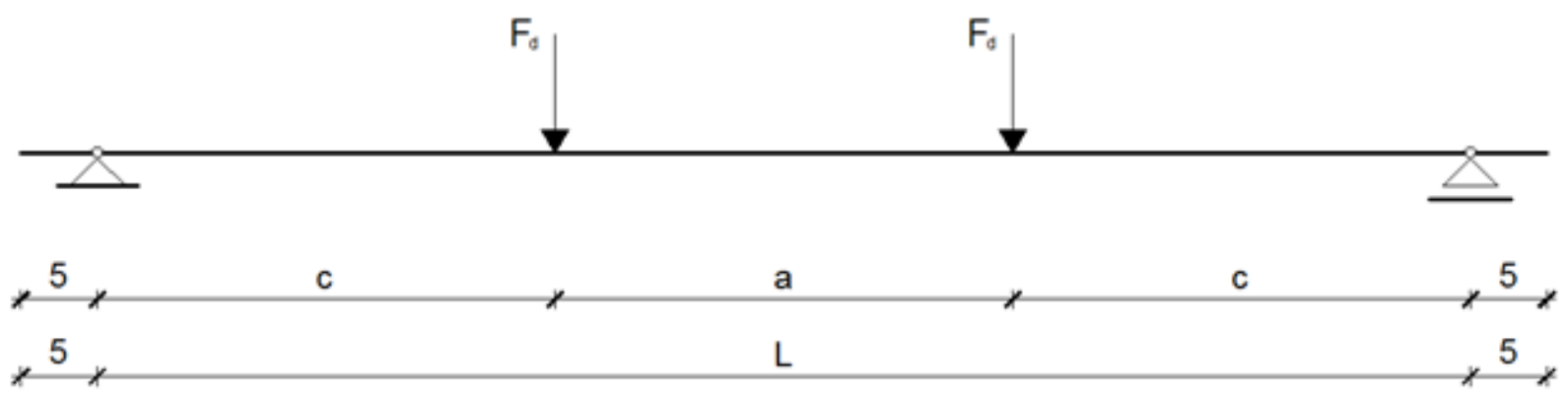

Figure 3 Model of the tested beams

\section{RESULTS}

Special attention was given to vertical kneading deformation at the force application area, where the finite element mesh was additionally refined to acquire more precise results (Figures 4 and 5). Figure 4 shows the finite element mesh of the whole beam. Figure 5 presents in more detail the force application area and the normal stress distribution at the concentrated force area. 


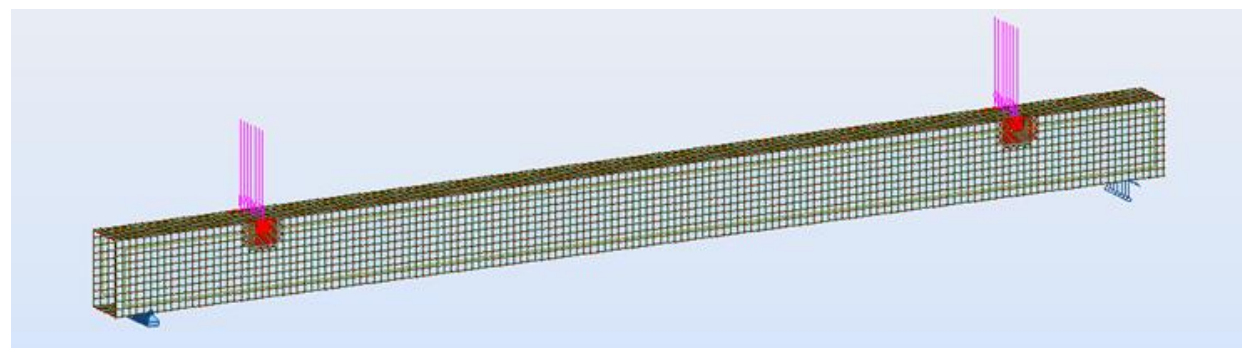

Figure 4 Finite element mesh of the whole beam
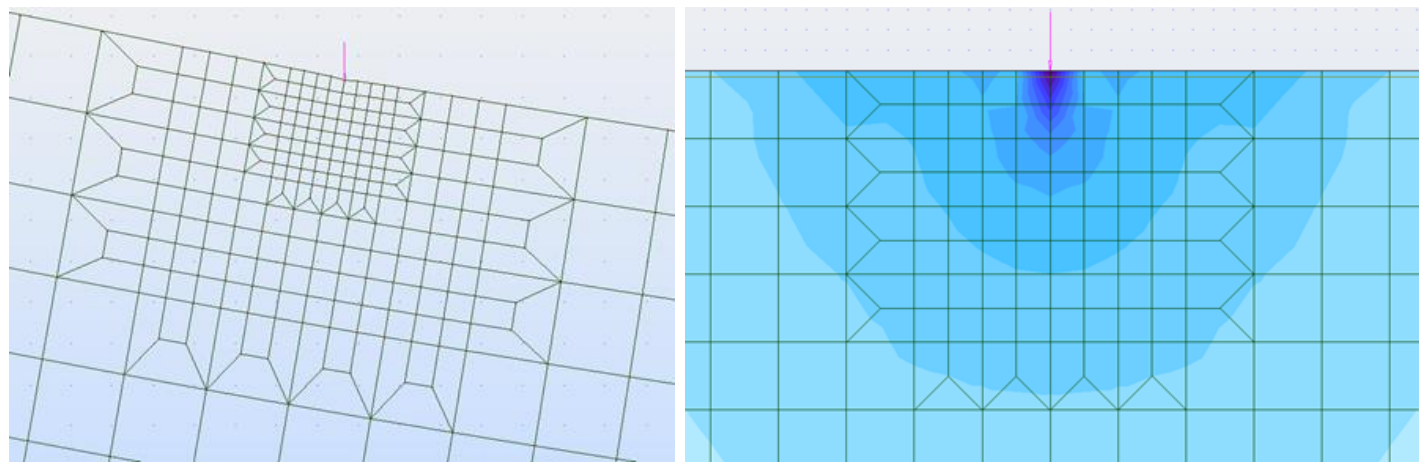

Figure 5 Finite element mesh and normal stress distribution in the concentrated force area

The deformations at the supports investigated in [3] and those at the force application area investigated in this paper were compared. Figure 6 shows the results, where the vertical axis represents the force values, and the horizontal axis represents kneading deformation.

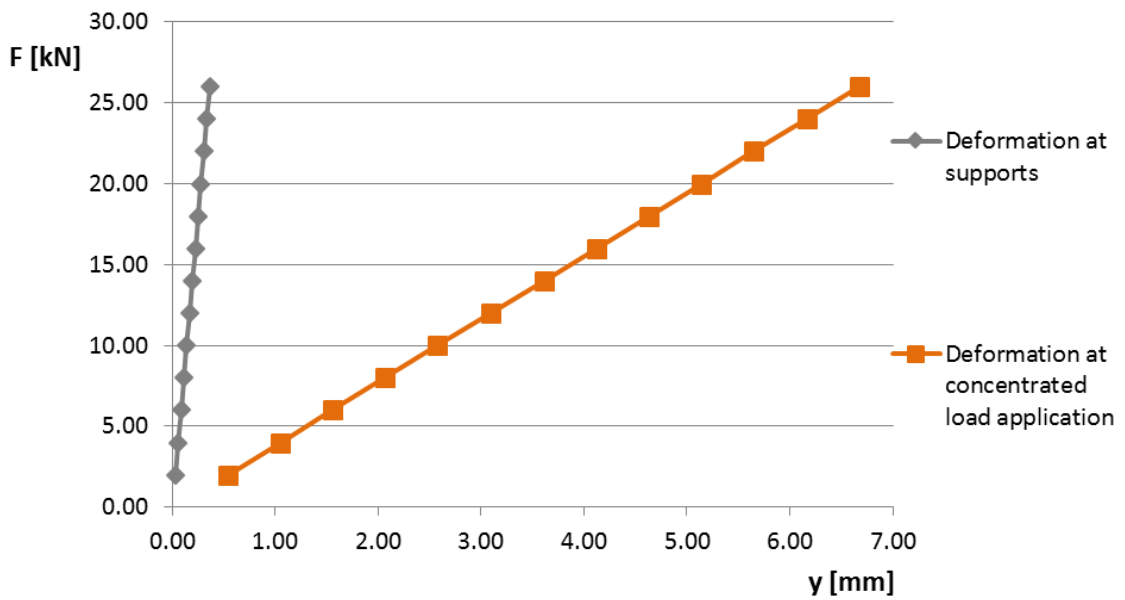

Figure 6 Comparison of the deformations at the supports and at the force application areas

The results are shown in dimensionless diagrams, where the vertical axis represents the $F / F_{p}$ ratio, and the horizontal axis represents the $y / f$ ratio. The $F / F_{p}$ ratio represents the ratio of the applied force to the initial force, whereas the $y / f$ ratio represents the ratio of kneading and mid-span deformations. The beam with a span of $90 \mathrm{~cm}$ was first analyzed. The results are shown in the diagrams in Figure 7, which represent the beams with the distance between the forces and the supports equaling $6 \%, 11 \%$, and $17 \%$ of the beam span. A comparison of the results was performed for the deformation at the supports and at the force application areas.

Subsequently, the beam with a span of $140 \mathrm{~cm}$ was analyzed. The results are shown in the diagram in Figure 8. The diagram presents the results for all the three span distances (i.e., $6 \%, 11 \%$, and $17 \%$ ). A comparison of the results was performed for the deformation at the supports and at the force application area.

The beam with a span of $240 \mathrm{~cm}$ was finally analyzed. The results are shown in the diagram in Figure 9 . The diagram presents the results for all three span distances (i.e., $6 \%, 11 \%$, and $17 \%$ ). A comparison was performed between the results for the deformation at the supports and at the force application areas. 


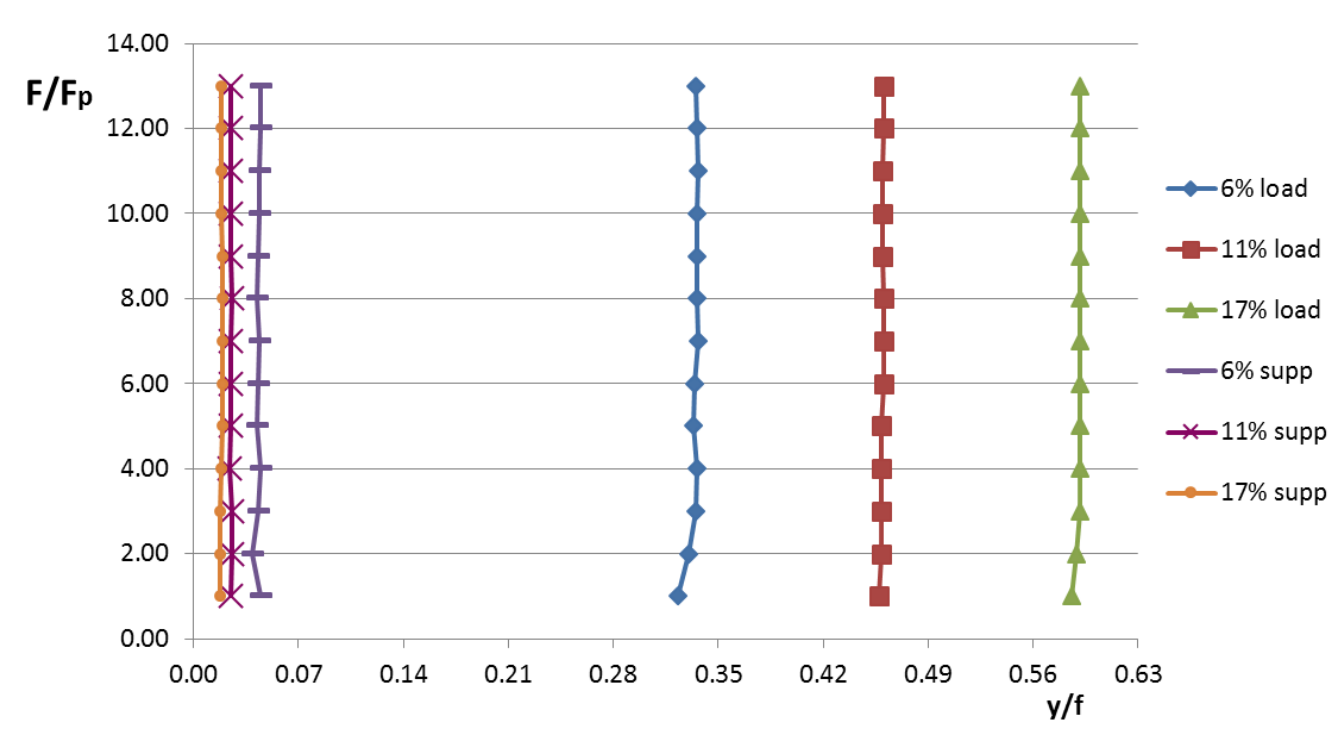

Figure 7 Results for the beam with a span of $90 \mathrm{~cm}$

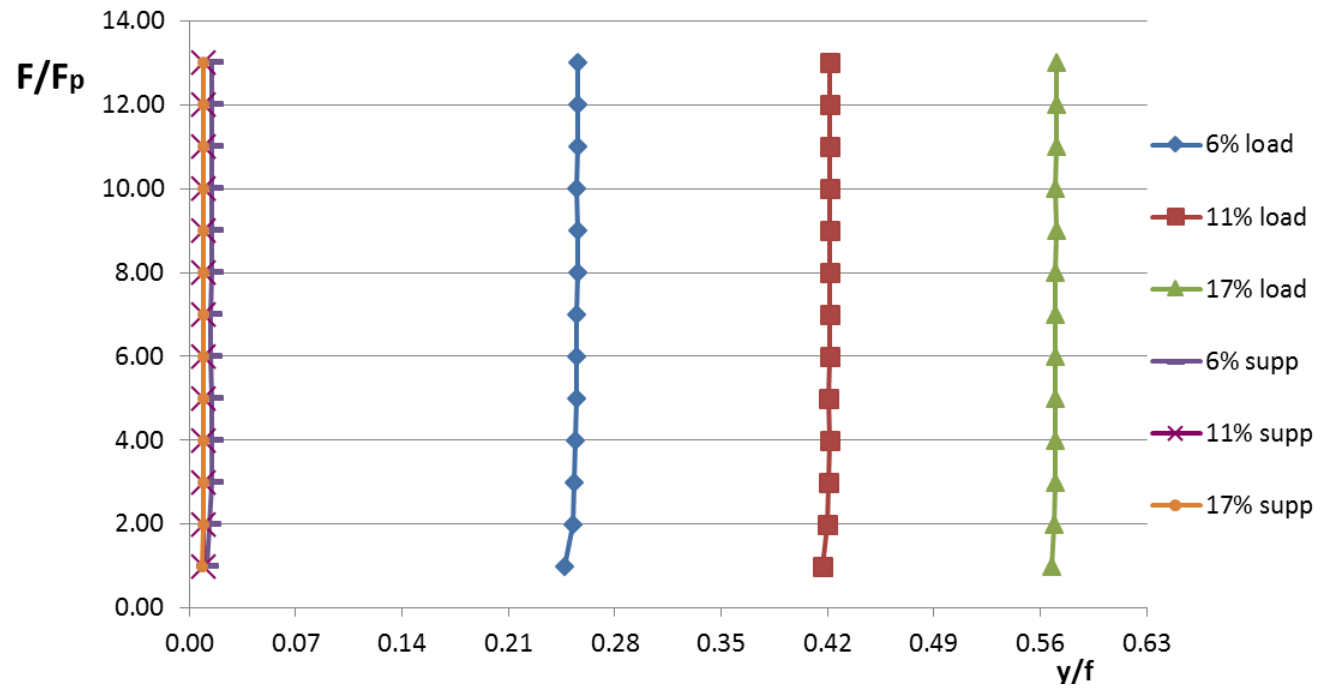

Figure 8 Results for the beam with a span of $140 \mathrm{~cm}$

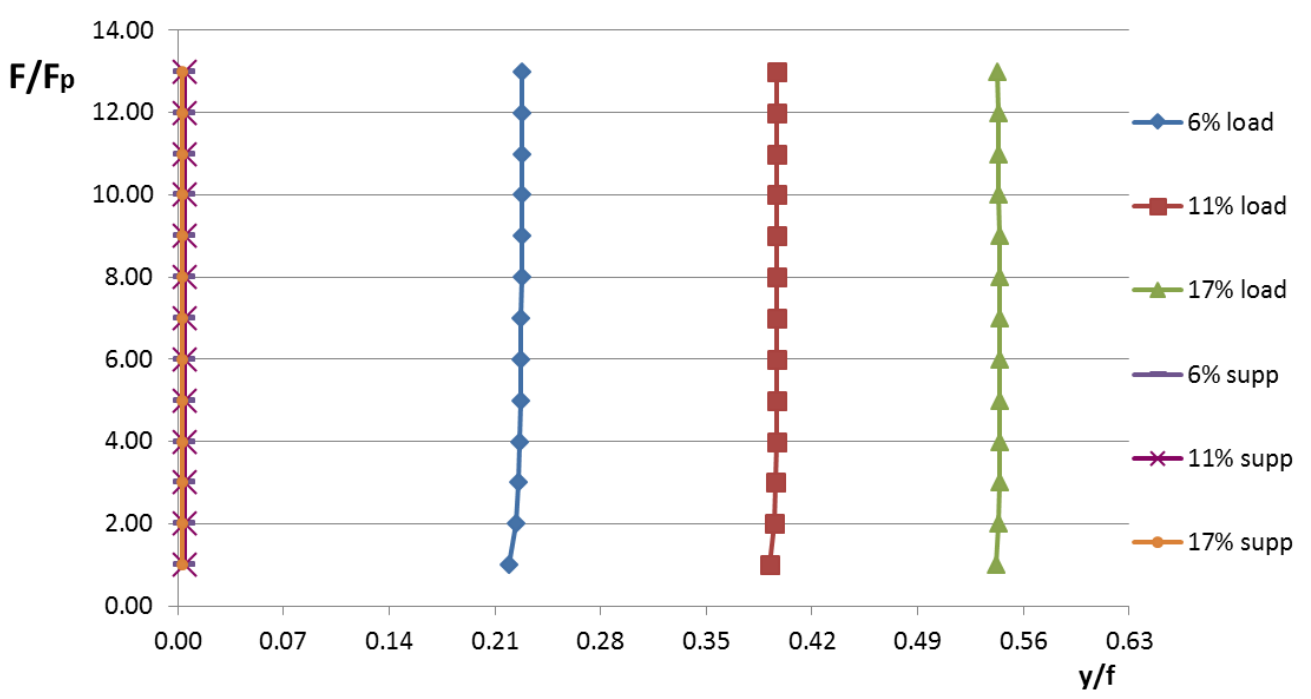

Figure 9 Results for the beam with a span of $240 \mathrm{~cm}$ 


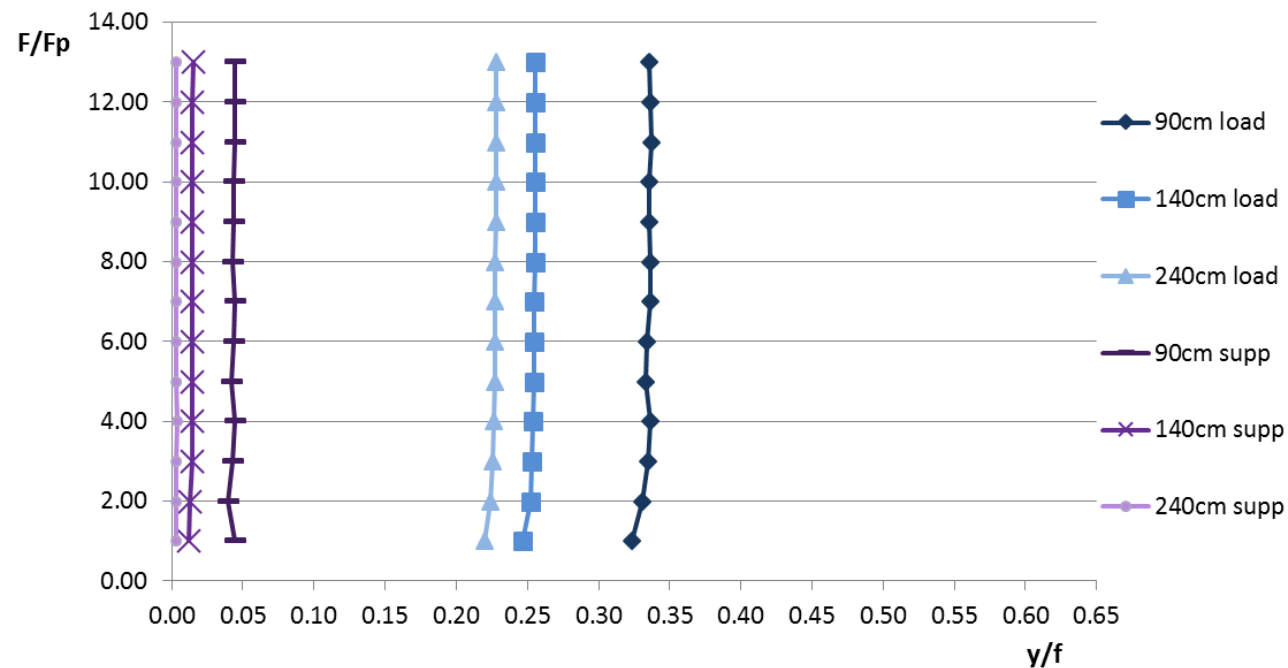

Figure 10 Diagram for the $6 \%$ span distance of the force

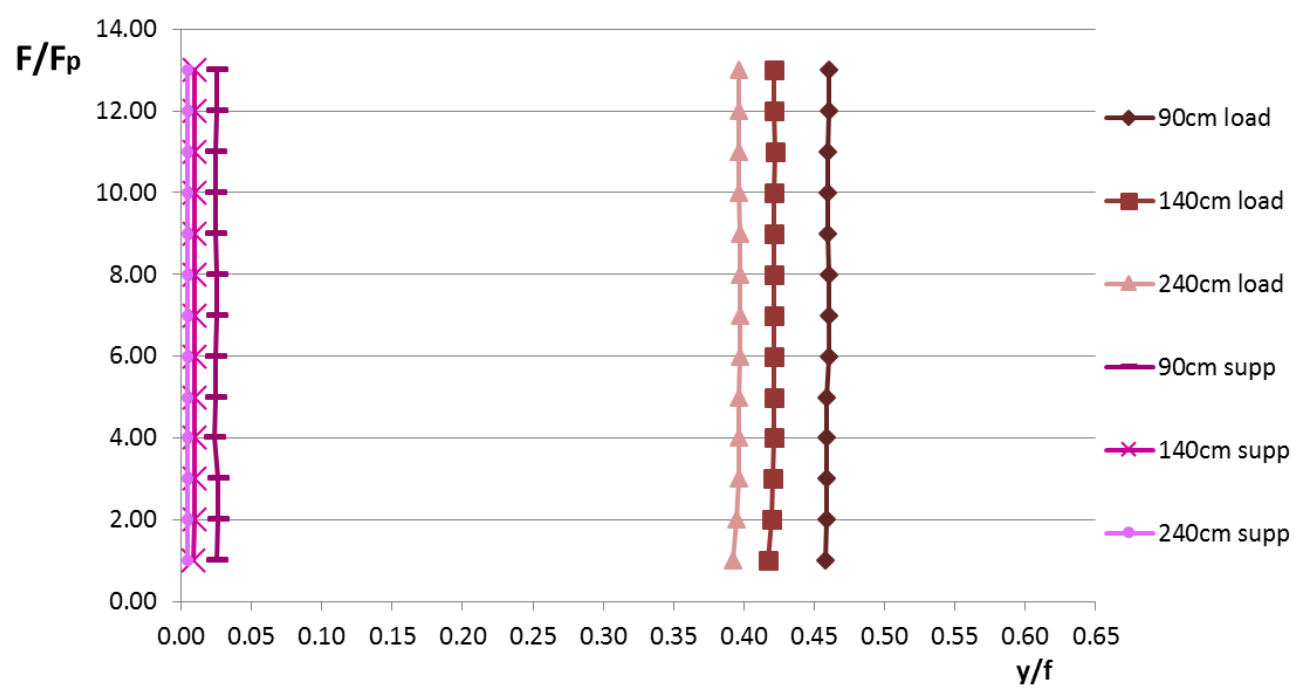

Figure 11 Diagram for the $11 \%$ span distance of the force

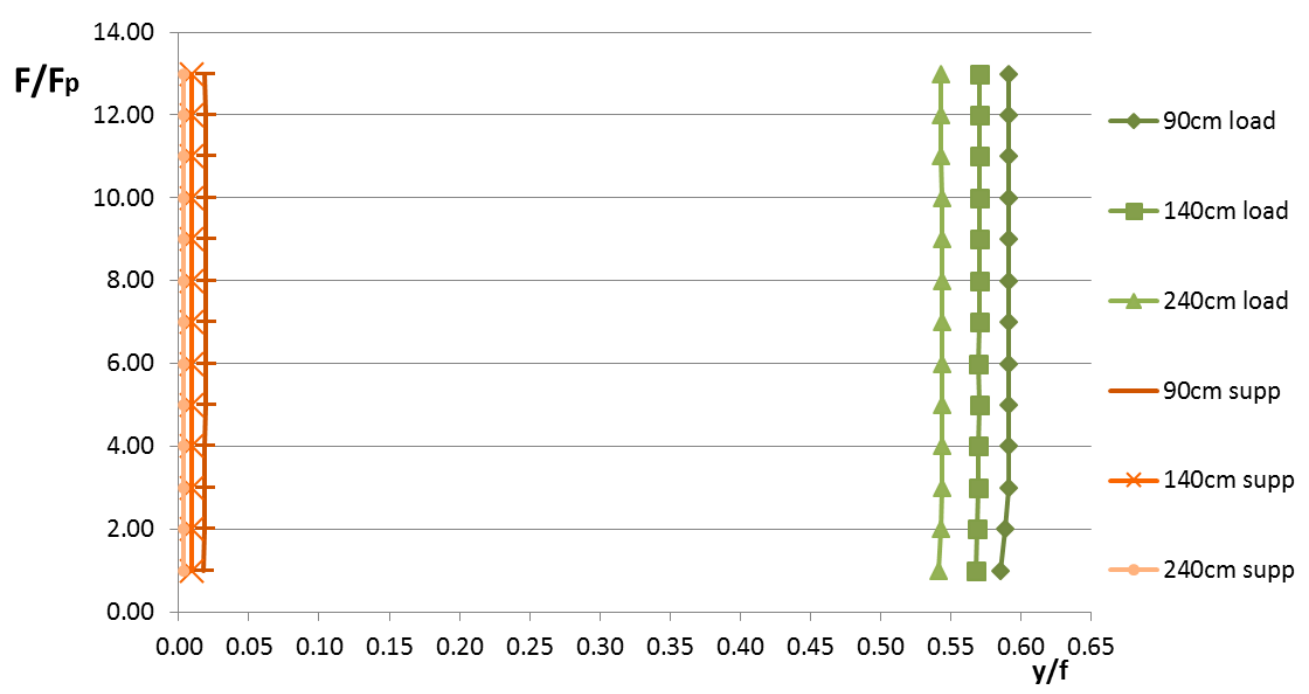

Figure 12 Diagram for the $17 \%$ span distance of the force 
Figure 10 shows the combined results for the $6 \%$ span distance for beams with 90,140 , and $240 \mathrm{~cm}$ spans. An additional analysis was conducted for the deformation at the supports and at the force application areas for all three cases.

The diagram in Figure 11 shows the results for the analyzed beams with spans of 90,140 , and $240 \mathrm{~cm}$ and $11 \%$ span distance of the force. A comparison of all three beams was then performed, as in the two prior cases.

Figure 12 shows the diagram for the $17 \%$ span distance of the force for the beams with spans of 90,140 , and $240 \mathrm{~cm}$. The same comparison to the results from [3] was performed.

\section{CONCLUSION}

This study analyzed the deformation of hollow cross-sectional beams made of multilayer GFRP to emphasize the problem that such beams have under concentrated loads. The same problem occurred at areas of supports, albeit with smaller effect, than at areas of concentrated loads. This study investigated this problem. A non-linear analysis of three different beams was performed in a manner, where the distance of the force from the supports was varied, and the deformation at the concentrated load point was observed. These results concluded that high stresses occurred at areas, where concentrated loads were applied. This occurrence produced an unfavorable effect that led to brittle failure. In this case, the deformation decreased and kneading became larger because the concentrated forces were closer to the supports. Furthermore, the deformation became larger and kneading decreased because they were located farther from the supports. The results were presented by dimensionless diagrams. Therefore, they can be used when assessing the possible critical places of concentrated loads and/or supports for similar beams.

\section{References}

[1] Šimunić, Ž. 2006: Polimeri u graditeljstvu, Sveučilište u Zagrebu, Građevinski fakultet, Zagreb (in Croatian)

[2] Gerdeen, J.C.; Lord, H.W.; Rorrer R.A.L. 2006: Engineering Design with Polymers and Composites, CRC Press, Boca Raton

[3] Junušić, S.; Štefić, T.; Jurić, A. 2014: Deformation in multilayer fiberglass beams at different positions of concentrated load, e-GFOS (8), pp. 27-36, http://dx.doi.org/10.13167/2014.8.4

[4] Štefić, T. 2013: Mogućnost primjene višeslojnih ploča od kompozitnih materijala kao nosivih konstrukcija u visokogradnji, Sveučilište u Splitu, Fakultet građevinarstva, arhitekture i geodezije, Split (in Croatian)

[5] ASTM Standard D3039, Standard Test Method for Tensile Properties of Fiber-Resin Composites 2008: ASTM International, West Conshohocken, Available on www.astm.org (Accessed 1.6.2016.)

[6] Autodesk Robot Structural Analysis Professional 2010: Version 23.0.0.3128, Autodesk, Inc. 